\title{
Advancing Intercultural Competence among National Secondary School Students through Malaysian English Literary Texts (MELT)
}

\author{
Manjet Kaur Mehar Singh*, Fatin Najwa Amelia Marsani \\ School of Languages, Literacies and Translation, Universiti Sains Malaysia, Penang, Malaysia \\ Corresponding Author: Manjet Kaur Mehar Singh, E-mail: manjeet@usm.my
}

\begin{abstract}
ARTICLE INFO
Article history

Received: March 08, 2018

Accepted: May 11, 2018

Published: September 01, 2018

Volume: 7 Issue: 5

Advance access: July 2018

Conflicts of interest: None

Funding: The research is

financed by the

Fundamental Research

Grant (FRGS) Research

Fund provided by

Ministry of Education,

Malaysia

ABSTRACT

The aims of English literature component in the Malaysian English Language curriculum as outlined by the Ministry of Education (MoE) (2009) are to improve the students' proficiency through reading, respond to texts, understand and appreciate other cultures and relate events and characters to one's own life. Therefore, the purpose of this research is to assess the intercultural elements in a short story titled Tanjung Rhu used as the Form Four English literature component text and another Malaysian English literary text (MELT) titled Deep Fried Devils. The assessment of intercultural elements in the two MELTs will provide opportunity for a MELT that can better advance intercultural competence among national secondary school students. Qualitative data comparing two MELTs is collected using a checklist for selecting and evaluating multicultural MELT by Harper and Brand (2010). Content analysis comparison of the story, characters, plot and settings was conducted using Atlas.ti 7.0 version software. Findings indicate Deep Fried Devils has better intercultural elements to promote intercultural competence among Malaysian national secondary school students of diverse ethnicity. This research recommends Deep Fried Devils to be considered as part of the English literature component in next text selection cycle by the Malaysian MoE or as extensive reading material for Form Four students to develop their intercultural competence. The findings provide insights to guide policy makers, curriculum designers and literature text selection committee in recognizing cultural diversity elements in MELT and choosing suitable MELT for promoting intercultural competence among Malaysian national school students.
\end{abstract}

Key words: English Literature; Intercultural Competence; Intercultural Elements; Malaysian English Literary Text (MELT)

\section{INTRODUCTION}

Promoting unity among national secondary school students has always been a top priority agenda of the Malaysian Ministry of Education (MOE). In this respect, the responsibilities of national schools are not only constrained in providing education for academic excellence and training students to excel in sports and co-curricular activities but also with the task of providing knowledge and educating Malaysian students on multiculturalism to maintain positive relationships among themselves. This responsibility is crucial due to the nature of Malaysia as a very pluralistic society. Malaysian pluralist society is characterized by multiple races, ethnics, and cultural differences (Jamil \& Raman, 2011) with three major races that are the Malays (50.1\%), Chinese (22.6\%), and Indians $(6.7 \%)$. As a country that is made up of multiple ethnic groups, each group portrays their own unique culture and heritage including languages, identities, and values (Najeemah, 2008). Thus, in instilling unity among national school students, Pillai, Menon and Vengadasamy (2016) asserted that English literary text has been used gainfully in the Malaysian curriculum during English language period for language learning as well as a tool to showcase the diversity of Malaysians and ultimately become a tool in forging nation building.

In Malaysian secondary schools' curriculum, Ong, Ong, Ong and Ting (2010) and earlier supported by Badger, and MacDonald (2007), MacDonald, Badger and Dasli (2006) and McKay (2001) one avenue of familiarizing the students with variety of cultures and at the same, help in building positive relationship between the teacher and the students, as well as among the students is through reading activity in the classroom. MoE $(2010,2011)$ commended the role of English literature component that is integrated in English language classroom to engage students with text and enhance their English language proficiency through intercultural reading, as well as understand and appreciate Malaysian local cultures that are represented in the English literature component. The edge provided by intercultural reading activity is that it has always been a medium that bring readers across borders, build bridges across cultures and communi- 
ties and enable the readers to see and analyze critically the complex texts that influence the readers' beliefs, everyday lives, moral commitments, and social investments (Luke, 2003, p. 20).

In this context, Malaysian English Literary Text (MELT) is the best medium to reflect the cultural diversity of the Malaysian plural society. For this research, a text is considered MELT if the elements and textual characteristics, such as the story, characters, setting, and plot includes and describe cultures, values, and practices of Malaysians. According to Quayum (2007), none of the ethnic groups in Malaysia is the native speaker of English language, however, English literary text has become the Malaysians or local authors' choice of read, and as a part of their efforts to incorporate local context, through a process of appropriation and infusion of local blood.

Within texts in Malaysian English literature component used for Malaysian Form Four students by MoE for the year $2015 / 2016$, only one short story was by a local writer, while the other short stories, poems and dramas were by foreign writers. According to Wan Kamariah (2009), foreign writers have the tendency to present different cultural norms and cultural representations in their writing. Lacking knowledge of the culture that the foreign writers represent in the texts creates distance between the texts and the Malaysian students as they might interpret the message that the author is trying to deliver differently, which will then lead to inappropriate cultural representation. As mentioned by Siew, Daljeet, Yow, Mun, Malenee and Anuar (2015), if students in learning environments are not aligned with their own culture, they will experience significant conflict. This will lead to struggle in trying to maintain a connection with their local cultures.

Vethamani (2004) argued that the choices of text for English literature component syllabus have a strong preference towards American and British literature text that are known worldwide. However, there is also a crucial need to consider Malaysian literature by local writers to be introduced in national schools. Instead of using foreign literature, Vethamani (2004) recommended that integrating Malaysian based literature in English language in the national syllabus would create a more familiar setting and cultural environment for student learning. Thus, it will indirectly allow the students to enjoy MELT as the local characters, settings and cultural issues represented by the local writers can be identified easily as the students are more familiar with local settings as compared to foreign cultures that are promoted in foreign literary texts.

It is also crucial to use MELT in English literature component as a medium to study and expose the students to Malaysian culture especially revolving around the three main ethnic groups (Malay, Chinese and Indian) and cultivate reading habit as Jia (2017) contended that the popularity of literature as a subject among Malaysians is declining as literature is regarded as elitist, a difficult subject to study and a difficult subject to score well in. Furthermore, Manjet, Marsani, Jaganathan, Karupiah, and Abdullah (2017) and Marsani, Manjet, Jaganathan, Karupiah and Abdullah (2016) also concurred that constructive initiatives and inter- vention in school reading programmes to improve the level of intercultural knowledge and behaviour among Malaysian secondary school students are acute. However, the selection of texts used for English literature component in national schools was found lacking in terms of promoting local intercultural scenes. Ganakumaran (2003) and Wan Kamariah (2009) mentioned that foreign texts were found to be more in numbers as compared to local texts. Secondly, the texts in the English literature component are supposed to be renewed once every 10 years (Pillai, Menon \& Vengadasamy, 2016) since it was first implemented in 2001. Surprisingly, there were not many changes during the text selection in the second cycle (2011-2020) by the MoE in terms of MELT. Therefore, this research aims to compare two literary texts and identify the text that promotes Malaysian intercultural elements highly compared to another.

\section{LITERATURE REVIEW}

\section{English Literature in Malaysian Educational System}

According to Ganakumaran (2003), English literature component was first introduced in 2000 by MoE and the selected texts were written by both English and Asian writers. The objective of the literature component is to enrich and enhance Form Four students' English language proficiency level using English literary texts (MoE, 2011). Ganakumaran (2003) further added that the main aims of the literature component are to enhance students' proficiency in English language through the study of a set of prescribed literary texts; to promote interest in reading in English language; to appreciate aesthetic values and the beauty of the English language; and to know and understand other cultures and universal values. Consequently, a variety of complete literary works in English, translations, and adaptations or simplified versions of novels are used to achieve these aims.

When the literature component was first incorporated in English language syllabus of Malaysian secondary schools, the aim is to assist students to enjoy reading good written literary texts for self-development and pleasure. Concurrently, the students are to share their ideas, thoughts, beliefs, and feelings that are related with the societies, cultures, values and traditions that they learned from the texts (Curriculum Development Centre, 2000). Ling and Eng (2016) later concurred with Ganakumaran (2003) that English literature component in school plays a significant role in exposing the students to other people's cultures, traditions, beliefs and customs. Thus, it is important for the selection of English literary texts to be culturally diverse as it can help in promoting unity among the national school students by improving their knowledge about other cultures and their intercultural competence simultaneously.

Past research concerning text selections for English literature component as a part of English language syllabus for Malaysian national secondary school students has resulted in different feedback and conclusions by researchers (Othna \& Melur, 2016; Sivapalan \& Subramaniam, 2008). Accordingly, research by Othna and Melur (2016) on the evaluation of English literary text used by Form Four and Form Five Ma- 
laysian national secondary school students concluded that the English literary text in English literature components for the students did not give take into consideration the cultural practices of the students as most of the texts in all genres were by foreign writers and the elements in the texts were too foreign for the students. Hence, students without background knowledge of the foreign countries' cultural practices could hardly understand the text and they also found it challenging to improve their level of English language proficiency at the same time.

Earlier, Kaur and Mahmour (2014) examined the role of the English literature component in national curriculum and indicated various fundamental issues arising from the implementation of English literature component such as the lack of cultural elements in the English literature component. The researchers agreed with Ganakumaran (2003), Ghazali, Setia, Roszainora, Muthusamy, and Jusoff, (2009), and Vethamani (2004). It concluded that it is challenging to select the appropriate texts that play a crucial role in the literature component. The texts chosen to need to be manageable in terms of the language used, the cultural aspects and also be of interest to the students. Secondly, the text must provide more meaningful engagement as it would motivate students to engage in literature reading and identify themselves with the local characters and issues. Hence, the researchers above stressed that the interest factor of students must take precedence in any text selection tasks.

\section{Developing Intercultural Competence through Reading}

According to Bennett (2008) intercultural competence is a set of beliefs, values, and behaviors learned, shared and practiced by a group of interacting persons. It is also a combination of capacities and of cognitive, affective and behavioral characteristics which when applied, allowed effective and appropriate interaction in a variety of cultural contexts. Earlier, Bennett (1998) also quoted that knowledge as a part of intercultural competence. Intercultural knowledge is a systematic way to measure a person's capacity to identify their own culture with others, and adapt empathically and flexibly to unfamiliar ways of being. In agreement to Bennett (2008), Ashwill and Hoang Oanh (2009) later mentioned that intercultural competence is a set of skills that enables a person to function effectively according to different cultural settings, with people of different origins, which include the understanding and knowing the existence of cultural differences and the right ways to apply their knowledge.

In addition, Bradella (2003) concurred with Ashwill and Hoang Oanh (2009) that intercultural reading contributes to self-reflection and imaginative immersion in otherness among students hence, fostering intercultural skill. In return, there will be improvements in students' intercultural competence or students' ability to adapt to different cultures, with people of different origins, which include understanding and knowing the existence of cultural differences and the right ways to apply their existence knowledge. In developing intercultural competence among national secondary school students, exposing Malaysian secondary school students to MELT is encouraged as one of the methods to facilitate inter- cultural learning process. Besides that, the ability of reading to construct sociocultural images and help in reflecting different ways of experiencing the world with the right literary texts has been widely acknowledged (González-Rodriguez \& Puyal, 2012). Therefore, there is the need to expose students to MELT as it does not only contribute to emotional development of the students (Ghosn, 2002), but at the same time, nurture interpersonal and intercultural attitudes of the students.

Furthermore, Adam and Harper (2016) indicated that literary texts with diverse cultural elements will help the students to identify different heritages and values of other cultures. As such, readers should be exposed to literary texts that convey respect and acknowledgement of diversity as part of the cultural values. For example, the colour black symbolizes death in Western society. However, death is linked to the colour white in the Muslim society (Bortoli \& Maroto, 2001). Thus, the misconception of cultures tends to happen without the justification from the right source of cultural reading materials. Skopinskoja (2003) argued and mentioned that Malaysian textbooks play an important role in developing students' awareness of their own cultural identity, which includes providing the right material that promotes cultural awareness of the target culture. Thus, in promoting intercultural reading through literature, aspects such as plain language, proper organization, as well as thought-provoking themes equally play important roles.

The background knowledge of the learner interacts with the reading task and illustrates how a student's knowledge and previous experience with the world is crucial in deciphering a text. The ability to use schemata or background knowledge is seen to play an important role in one's trial to comprehend a text (Pardede, 2010). Kitao (1990) describes that interaction between readers' knowledge and the text results in comprehension while Gunning (1996) asserts that past experiences lead to the creation of mental frameworks that help a reader make sense of a new experiences. Anderson (1994) mentioned that when readers cannot locate a schema that fits a text, readers may find it incomprehensible. In some cases, readers might not have a schema that is significant to the text or assistance is needed to activate the pertinent schema to be able to comprehend the text.

Therefore, in finding the suitable MELT that can accommodate the students with local intercultural elements, the objective of this research is to assess the intercultural elements of two literary texts to identify which text is better to develop intercultural competence among Form Four national school students. The MELTS analyzed are a short story from the current Form Four English literature component syllabus titled Tanjung Rhu by Mingfo Ho and another short story not currently used in the current Form Four English literature component syllabus by a Malaysian writer, Shih Li-Kow titled 'Deep Fried Devils'.

The storyline of Deep Fried Devils reflects what it means to be Malaysian. As such, the storyline is capable of nurturing the mentality of the nation by portraying a truly unified society in which peace is dominant. According to Farahmandian (2012), Deep Fried Devils is replete with themes common 
in Malaysian literature; themes such as search for identity, ethnic pluralism and cultural multiplicity. At the same time, even the themes which seem to have been repeated over and over, follow the same objective of forming a national identity and bridging the ethnic gap, more successfully than other texts. As for Mingfo Ho, the author of Tanjung Rhu, she was born in Rangoon and raised in Singapore and Thailand. Tanjung Rhu was published in 1986, with Singapore as the setting and the time frame in the study goes back and forth between the present and past time.

\section{METHOD}

Qualitative research design in the context of content analysis is used to evaluate intercultural elements in two selected MELTs. Miles and Huberman (1994) describe content analysis as archival strategies, whereby the main research subject relates to documents. According to William, Donnelly, and Arora (2016), evaluative based research is a systematic assessment of the worth or merit of the subject and the purpose of evaluative research is to provide useful feedback to the readers. Formative evaluation is used specifically in this research to evaluate both MELTs. Formative evaluation by doing content analysis is used to help identify a text that is suitable in advancing intercultural competence among national secondary school students.

\section{Research Procedures}

The three steps data analysis by Miles and Huberman (1994) namely data reduction, data display and conclusion drawing is used as a part of the procedures. In analyzing the data from the two MELTs, the texts were read thoroughly. Pages and lines with the elements and characters based on the checklist was marked by using memo pad from the data analysis software. Qualitative data analysis involved identifying, coding, and categorizing the checklist based on the text, hence, Atlas. ti version 7.0 was used in analyzing the MELT. Based on the

Table 1. Coding system

\begin{tabular}{llll}
\hline Codes & & \multicolumn{2}{c}{ Meaning } \\
\hline E1CA & & & Element 1 Character A \\
E2CA & E2CB & E3CC & Element 2 Character A, B \\
E3CA & E3CB & & Element 3 Character A, B, C \\
E4CA & E4CB & & Element 4 Character A, B \\
\hline
\end{tabular}

elements in the checklist such as story, characters, setting, and plot, the textual characteristics in each of the element is used as guidance. The same procedure was repeated for each element of both stories. The analysis for both MELTs then is compared. The findings obtained were used to answer the research questions.

The purpose of developing codes is mainly to ease the data classification and data analysis. The codes were constructed based on the elements and textual characteristics of the checklist. Table 2 shows the codes used while analyzing the data. The elements represented by number 1 is story, number 2 is character, number 3 is settings, and element number 4 represents plot. The alphabets $\mathrm{A}, \mathrm{B}$, and $\mathrm{C}$ after 'Characters' represent the textual characteristics marked accordingly in Table 1.

After the texts were coded, marked, and updated into Atlas.ti version 7.0 software, two general worksheets were then generated. The worksheet for Deep Fried Devils and Tanjung Rhu were generated separately through the software. These worksheets were used as a primary source in tabulating the data as according to the elements and characters to fulfil the objective of this research.

\section{Instruments}

The instruments used for this study are two MELTs, Deep Fried Devils by Shih Li_Kow and Tanjung Rhu by Minfong Ho. The second instrument is the adapted checklist by Harper and Brand (2010). Deep Fried Devils written by Shih Li Kow was published in Ripples by Silverfish Books Sdn Bhd in 2008. Ripples, which consists of 25 short stories was shortlisted for the 2009 Frank O'Connor Short Story Award (Shih-Li Kow, 2008). The reader was chosen for this research because the short stories in the reader utilized local cultures of Malaysians as its background theme. Besides that, 'Ripples' offers short stories with rich cultural elements especially cultural practices, traditions and customs that most Malaysians will be able to relate with especially in their daily practice. Thus, one of the short stories in Ripples, titled 'Deep Fried Devils' was chosen via random sampling as one of the MELTs.

The second MELT, Tanjung Rhu is selected from a group of short stories from the Form Four English literature component. The Tanjung Rhu is written by a Chinese-American award-winning author, Minfong Ho. The story was selected as a part of teaching material for the English Literature com-

Table 2. Adapted version of the checklist

\begin{tabular}{ll}
\hline Elements & Textual characteristics \\
\hline 1. Story & a. Overall, is this a high-quality story, independent of its multicultural aspects? \\
2. Characters & a. Is the lifestyle realistic? \\
& b. Are females as well as males depicted in leadership roles? \\
3. Setting & a. Does the story reflect a variety of places and times? \\
& b. Are urban, suburban, and rural settings represented realistically? \\
& c. Are cultural settings and geographical features represented accurately? \\
4. Plot & a. Are various conflicts presented for readers to explore and discuss? \\
& b. Are rigid boundaries of class, culture, religion, and ethnicity dismissed?
\end{tabular}


ponent of Four Four syllabus. Tanjung Rhu was purposively chosen as the MELT for this research as some of the elements and textual characteristics, such as the story, characters, setting, and plot includes and describes one of the major race's cultures, values, and practices in Malaysia.

In guiding the analysis of the MELTs, an adapted checklist for selecting and evaluating multicultural MELT by Harper and Brand (2010) is used. The analysis of the texts involved cultural elements comparison of Deep Fried Devils and Tanjung Rhu. The evaluation is based on four main elements that are story, characters, plot and settings. The aim of the checklist is to identify which MELT promotes better intercultural elements in developing intercultural competence among Form Four national school students. The checklist was chosen as the guideline of this research as it provides an evidence-based guideline to evaluate potential books for use in the classroom (Adam \& Harper, 2016). It is also developed to provide the teachers an evidence-based guideline to evaluate the potential texts for use in the classroom learning.

\section{RESULTS}

\section{Assessment of the Story}

Based on textual characteristic from the first element in the checklist, the quality of the story is divided into four quality categories, which are low, medium, good and high. A MELT is rated as low-quality story if it does not involve any cultural practice throughout the whole story, medium quality refers to the introduction of at least one cultural practice in the story. Good-quality is for a story that portrays two cultural practices, and high-quality story is rated for story with three or more cultural practices portrayed throughout the story (Table 3 ).
Using E1CA as a guideline, Tanjung Rhu is categorized as a good quality short story as it portrays two cultural practices throughout the whole story that is independent of its own multicultural aspects. Deep Fried Devils portray a very well diverse cultural background as the essence of the story. It is categorized as a high-quality short story as it portrays four cultural practices.

\section{Characters}

Tanjung Rhu and deep fried devils's character assessment is summarized in Table 4

\section{Setting}

Tanjung Rhu and deep fried devils's setting assessment is summarized in Table 5

\section{Plot}

Tanjung Rhu and deep fried devils's plot assessment is summarized in Table 6

\section{DISCUSSION AND RECOMMENDATIONS}

The story element shows that Deep Fried Devils has good quality storyline compared to Tanjung Rhu. Although both MELTs are independent of its multicultural aspects, the textual evidence from the text itself shows that Deep Fried Devils highlights more than three different cultural practices as compared to Tanjung Rhu that only promotes two different cultural practices. Besides that, Deep Fried Devils shows that Malaysia is a melting pot for multicultural diversity as more than three cultures can live harmoniously despite their

Table 3. Tanjung Rhu and deep fried devils's story assessment

\begin{tabular}{|c|c|c|c|c|c|c|c|}
\hline Chinese & & Foreign & & Malay & & Indian & \\
\hline $\begin{array}{l}\text { Tanjung Rhu } \\
\text { Ah Ma } \\
\text { (Mr. Li's } \\
\text { mother) speaks } \\
\text { Cantonese, one } \\
\text { of the Chinese } \\
\text { dialects. } \\
\text { Ah Ma still } \\
\text { practices } \\
\text { old Chinese } \\
\text { customs and } \\
\text { rituals, such } \\
\text { as prayers in } \\
\text { the altar room } \\
\text { for her dead } \\
\text { husband. }\end{array}$ & $\begin{array}{l}\text { Deep Fried } \\
\text { Devil } \\
\text { Lan Jie sells } \\
\text { yow cha } \\
\text { kwai, Chinese } \\
\text { twin crullers } \\
\text { and a round } \\
\text { version with a } \\
\text { glutinous rice } \\
\text { centre. } \\
\text { Ah Wai sells } \\
\text { noodles full } \\
\text { of pork, } \\
\text { beef, prawns, } \\
\text { squid, and } \\
\text { vegetable at } \\
\text { an all-night } \\
\text { coffee shop. }\end{array}$ & $\begin{array}{l}\text { Tanjung Rhu } \\
\text { Mr. Li, Helen } \\
\text { (wife) and Ying } \\
\text { (daughter) are } \\
\text { moulded in } \\
\text { modernism } \\
\text { practices. } \\
\text { Mr. Li and Ying } \\
\text { speak English } \\
\text { with each other. }\end{array}$ & $\begin{array}{l}\text { Deep Fried } \\
\text { Devil } \\
\text { Foreigners } \\
\text { from } \\
\text { Indonesia, } \\
\text { Bangladesh, } \\
\text { and Myanmar } \\
\text { were } \\
\text { introduced } \\
\text { as maid and } \\
\text { labourers. } \\
\text { Lan Jie uses } \\
\text { English to } \\
\text { promote her } \\
\text { pastries to } \\
\text { backpackers } \\
\text { and Rahimah } \\
\text { (Din's wife) } \\
\text { described the } \\
\text { backpackers } \\
\text { as mat saleh } \\
\text { or westerners. }\end{array}$ & Tanjung Rhu & $\begin{array}{l}\text { Deep Fried Devil } \\
\text { Din sells chakoi, } \\
\text { a pastry that } \\
\text { Lan Jie claimed } \\
\text { as a traditional } \\
\text { Chinese snack, } \\
\text { which is } \\
\text { equivalent to } \\
\text { yow cha kwai at } \\
\text { 'Din's Chakoi' } \\
\text { stall. }\end{array}$ & $\begin{array}{l}\text { Tanjung } \\
\text { Rhu }\end{array}$ & $\begin{array}{l}\text { Deep Fried } \\
\text { Devil } \\
\text { Din had } \\
\text { his } \\
\text { breakfast } \\
\text { at Indian } \\
\text { Muslim } \\
\text { restaurant } \\
\text { while } \\
\text { ordering } \\
\text { roti canai } \\
\text { and dhall } \\
\text { curry. }\end{array}$ \\
\hline
\end{tabular}


Table 4. Tanjung Rhu and deep fried devils's character assessment

E2CA $\quad$ E2C2

(Are lifestyles realistic?)

Tanjung Rhu

1.Ah Ma

A mother of nine, grandmother of thirty-four and great -grandmother of seventeen year old.

Speaks Cantonese

A traditional woman who keeps chickens in the garden and practises the old Chinese customs and rituals.

Particular and meticulous when it comes to taking care of the altar and performing her prayers.

Yearns to see Tanjung Rhu, where she used to live years ago.

2. Mr. Li

A successful businessman in the shipping sector

Has a happy childhood with his family in Tanjung Rhu.

Close relationship with his mother but does not open to her easily.

Modern in his ways and ideas makes sure no

one is about when he bows to show respect to his dead parents.

Patient and respectful - waits for mother to finish prayers although he must leave for office - does not hurry her

Filial - made sure funeral of mother is done in the right way, customs and tradition.

\section{Strict and}

does not entertain disrespect from the young - expects daughter to respect elders.

\section{Regrets not}

talking to Ah Ma and never listened when she spoke.

Tolerant - does not interfere in his mother's traditional ways

\section{Deep Fried Devil}

1. Lan Jie

A Chinese hawker that sells pastry for a living.

Ability to speak English to

promote her pastries to western backpackers.

Very outspoken about other

races stealing Chinese traditional recipes.

Protective towards her own culture's traditional recipe.

Lan Jie wanted to report to Chinese Traders Association about other races trying to steal Chinese traditional recipe and tamper them with new ingredients.

Meticulous about the request from her customers.

\section{Ah Wai}

An all-night coffee shop owner who is also a noodle chef.

A concerned friend to Lan Jie

when he asked about her

business and informed her about a new stall opened

nearby her stall, which the

owner happens to be her former maid.

3. Datin

Lan Jie's regular customer with a Malay driver.

Ignorant - she stopped in the middle of the road and blocked the traffic just to buy pastries from Lan Jie. She also named all her Malay drivers as Ahmad, $\mathrm{f}$ ollowed by the car that they

are driving as she cannot remember all their names.

\section{Driver}

Known as Ahmad who is

knowledgeable about food of other cultures.

\section{Din}

Owner of 'Din's chakoi' stall.

Bold and daring - He made a bold remark on racism issue by chasing Lan Jie to go back to her China and be with the Communist.

Patriotic - Protective towards Malaysian business from foreign workers and agreed to put his ego behind by cooperating with Lan Jie to report to Immigration Department about stalls owned by foreign workers.

6. Rahimah (Din's wife)

Defensive towards Lan Jie's accusation of her stealing

Chinese traditional business

by saying that it is an open market.

She's not sensitive with her words.
(Are females as well as males depicted in leadership roles?)

Tanjung Rhu Deep Fried Devil

1. Mr. Li 1. Din

Played the role Played the role of the head of the owner of of the family Din's chakoi of four. The stall. daughter and the wife are obliged to listen to him as role when he a father and a protected his husband in the stall and business family.

2. Ah Ma Played the role of Mr. Li's from Lan Jie's accusation of his business stealing her cultural traditional recipe.

mother. Mr.

Li listens to 2. Lan Jie her and tried to Played the role fulfil her wishes of the owner of in his own Chinese pastries ways. stall nearby 'Din's chakoi'.

Portrayed a very strong character as she does not hesitate to argue with Din, reporting illegal business to Immigration Department. 
Table 4. (Continued)

\begin{tabular}{|c|c|c|}
\hline \multirow[t]{3}{*}{$\begin{array}{l}\text { E2CA } \\
\text { (Are lifestyles realistic?) }\end{array}$} & & $\begin{array}{l}\mathrm{E} 2 \mathrm{C} 2 \\
\text { (Are females as well as males } \\
\text { depicted in leadership roles?) }\end{array}$ \\
\hline & $\begin{array}{l}\text { She called Lan Jie stupid for hiring foreign maid and she } \\
\text { talked down on Lan Jie for being } \\
\text { a Malaysian Chinese that sells chakoi. }\end{array}$ & \\
\hline & $\begin{array}{l}\text { 7. Lan Jie's Indonesian helper } \\
\text { Manipulative - she went missing from Lan Jie's stall after } \\
\text { she became familiar with Lan Jie's recipe for } \\
\text { her pastries and she opened a stall that } \\
\text { sells the same thing with her } \\
\text { Bangladesh boyfriend nearby Lan Jie's and Din's stalls }\end{array}$ & \\
\hline
\end{tabular}

different values, beliefs, and practices. Hence, the findings align with Bishop (1997) that suggested culturally diverse literature serves as a mirror or a window, whereby the students can see their own reflections or in this case, better insights of their own culture, and in addition, students can also peek into the cultures of their peers through MELTs.

In the context of characters, each MELT introduced characters with strong roles in representing their cultures and relevance in the story. In terms of realistic lifestyles, both MELTs have the same weightage, whereby Deep-Fried Devils introduced seven main characters with strong roles in portraying their characters with cultural values. In Tanjung $\mathrm{Rhu}$, four main characters play a very significant role and all four characters represent realistic lifestyles. However, the second textual characteristics, or the depictions of males' and females' leadership roles show that Deep Fried Devils has equal weightage of leadership role on both genders. The male character is represented by Din, whereby the female character is represented by Lan Jie. Both male and female characters show positive leadership roles that could be great examples to the students. Although Tanjung Rhu also has two lead characters that represent leadership roles, the characters are bound to be a leader due to relationship with family members, such as mother (Ah Ma) and son (Mr. Li). In this case, one is obliged to follow the other as they are bound with the family bondage. Rosch (1993) suggested that the best books break down borders as they change our views of ourselves. Agreeing to that, characters portrayal in MELT plays a very important role in building the students' emotional development, as well as nurturing interpersonal and intercultural attitudes of the students (Ghosn, 2002).

In comparing the settings of both MELTs, Deep Fried Devils, however, used a very limited timeline whereby Tanjung Rhu plays with the past flashback and the present as the theme of the short story itself is traditional values vs. modern cultural values. The tradition in the short story was represented by the older generation's cultural practices, hence, the flashback from the past is showcased. Besides, the title of the MELT itself shows that Tanjung Rhu plays a very significant role throughout the short story. Other than that, another setting in Tanjung Rhu with a very important cultural representation is the altar room in the main character's house. The short story, Deep Fried Devils, however, introduced all three major cultures' spots to eat food that are associated to those ethnicities such as Malay and Chinese hawkers, Chinese coffee shop, and Indian Muslim restaurant. Besides that, the author also represented the geographical feature and the cultural issue precisely. Hence, Deep Fried Devils has better settings' elements.

In a study of developing intercultural competence through literary texts among school students, Garza (2008) found that the selection of reading materials and reading activities in classrooms to promote intercultural competence is important as they allow students to broaden their perspectives and familiarity of cultures other than their own. Magos (2015) also highlighted the same issue in educating Malaysian students with intercultural values and in choosing the right literature to promote intercultural reading, students must be introduced to texts that suit their interest. Therefore, the plot of a MELT plays a very significant role to attract the students' interest and attention, and at the same time develop their intercultural competence. In Tanjung Rhu, the conflicts revolve around two main issues that are generation gap and traditional values vs. modern cultural values. These issues are interrelated with each other whereby the younger generation is less likely interested in embracing the traditional cultural practices as part of their lifestyle. The conflict in Tanjung Rhu also strongly relates to the students' daily life. However, there is no rigid boundary of class, culture, religion, and ethnicity portrayed in Tanjung Rhu. In Deep Fried Devils, however, interracial harmony issue is prioritized throughout the whole story, whereby two major races in Malaysia were fighting over the ownership of traditional recipes. Yet, the conflict was solved at the end when both races agreed to protect their ancestors' recipe from being stolen by foreigners who were also doing business as hawkers selling foodstuff at the same area. Both races united as Malaysians once an element of foreign competition is introduced. Other than that, in Deep Fried Devils, the main character did not retaliate in a verbal argument with slurring racial remarks when was provoked. This shows that Deep Fried Devils also promotes values such as tolerance, patience, as well as bravery, which are the key to sustaining a harmonious multicultural community in a country such as Malaysia.

The comparison of the intercultural elements of both MELTs shows that one MELT promotes better intercultural elements than the other. Overall, Deep Fried Devils provides 
Table 5. Tanjung Rhu and deep fried devils's setting assessment

\begin{tabular}{|c|c|c|c|c|c|}
\hline \multicolumn{2}{|c|}{$\begin{array}{l}\text { E3CA } \\
\text { (Does the story reflect a variety of places and times?) }\end{array}$} & \multicolumn{2}{|c|}{$\begin{array}{l}\text { E3CB } \\
\text { (Are urban, } \\
\text { suburban, and } \\
\text { rural settings } \\
\text { represented } \\
\text { realistically?) }\end{array}$} & \multicolumn{2}{|c|}{$\begin{array}{l}\text { E3CC } \\
\text { (Are cultural settings and } \\
\text { geographical features represented } \\
\text { accurately?) }\end{array}$} \\
\hline \multirow{7}{*}{$\begin{array}{l}\text { Tanjung Rhu } \\
\text { The story took place in } \\
\text { Singapore and the time } \\
\text { frame revolves around the } \\
\text { past and the present. }\end{array}$} & Deep fried devil & Tanjung & Deep & Tanjung & Deep Fried Devil \\
\hline & The story took place in an open & Rhu & Fried & Rhu & Chinese traditional \\
\hline & area where hawkers' stalls and & & devil & & recipe was associated \\
\hline & restaurants are located. The author & Nil & & Nil & with China, as well as \\
\hline & $\begin{array}{l}\text { mentioned several countries } \\
\text { throughout the story to introduce }\end{array}$ & & Nil & & Malaysian Chinese. \\
\hline & the characters' origins. & & & & Lan Jie offered Din and \\
\hline & Lan Jie's stall & & & & Rahimah her mother's \\
\hline \multirow{4}{*}{$\begin{array}{l}\text { The past was described } \\
\text { as before the death of Ah } \\
\text { Ma. }\end{array}$} & Din's chakoi & & & & nyonya kuih recipe \\
\hline & Indian Muslim restaurant, & & & & and she mentioned \\
\hline & Restoran Hameed & & & & that her mother is \\
\hline & Ah Wai coffee shop & & & & second generation of \\
\hline \multirow{2}{*}{$\begin{array}{l}\text { The present was described } \\
\text { as after the death of } \mathrm{Ah} \\
\text { Ma. }\end{array}$} & Foreign workers' stalls & & & & $\begin{array}{l}\text { Nyonya descendent in } \\
\text { Malaysia. }\end{array}$ \\
\hline & 2. Countries' name dropping & & & & \\
\hline
\end{tabular}

2. Tanjung Rhu, a shipping port where Mr. Li grew up.

Chinese China and Malaysian Chinese

Din mentioned about chasing Lan Jie back to her hometown in China in a verbal argument when Lan Jie is a Malaysian Chinese.

The past was described as far as eighty years ago, the place used to have small shipyards where fishing boats were built.

The present was described by the buildings and skyscraper built in Tanjung Rhu.

3. Present day: Mr Li's office located on the 18th floor above Shenton Way, a central business district in Singapore.

This statement was referring to Tanah Melayu's condition back in time when the British brought other races from China and India to work in Tanah Melayu, which is now known as Malaysia.

Maid from Indonesia

The maid's boyfriend from Bangladesh

Backpackers from Western countries

\author{
Mr. Li's house with \\ many rooms, a garden, \\ and a swimming pool. \\ However, the altar room \\ in this house plays a \\ significant role in this \\ story. \\ The hospital where Ah \\ Ma passed away.
}

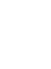

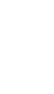


Table 6. Tanjung Rhu and deep fried devils's plot assessment

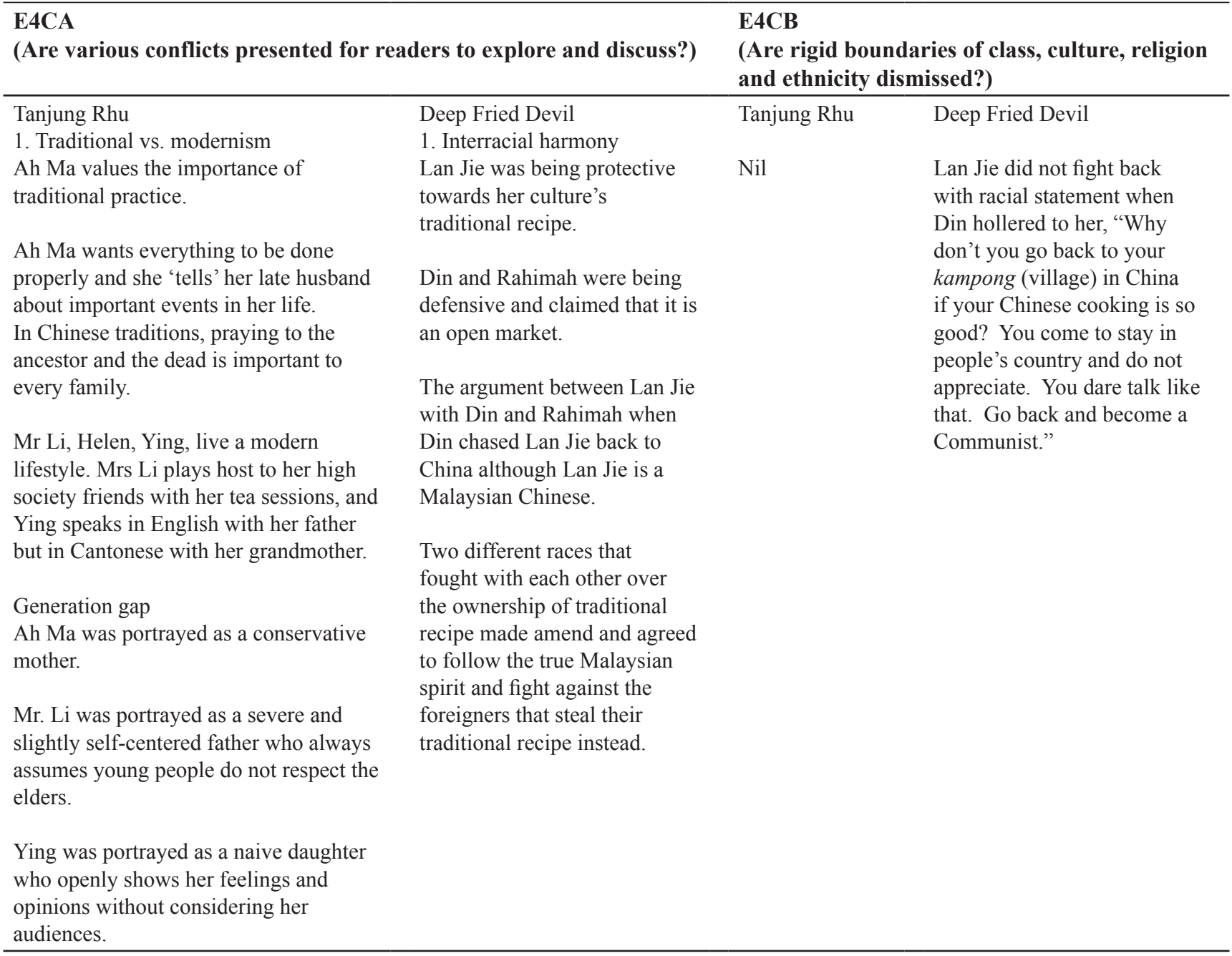

and shape the students' character and point of views based on what is portrayed in the literary texts (Kaur, 2002; Ganakumaran, 2003).

The findings of this research provided a guideline to promote positive development of intercultural competence through MELT as part of Form Four national secondary school English literature component. Texts such as Deep Fried Devils and similar texts should be incorporated in the English literature component of Form Four English language syllabus as the content could help to improve the students' intercultural competency due to its rich Malaysian based cultural background elements. Through sharing and discussions based on the relevant reading material, Malaysian national secondary school students would have better opportunities to improve their level of intercultural competence. Such integration would be the most significant contribution of this research as it will help the MoE to achieve its goal in inculcating unity in educational policy by improving the students' intercultural competence. This will indirectly help to provide a platform to promote unity among young Malaysians and at the same time fulfil one of the major goals of our educational policy, which is 'to inculcate, and nurture national consciousness through fostering common ideas, values, aspirations and loyalties to mould national unity and national identity in a multi-ethnic society' (Khader, 2012, p.270).

\section{CONCLUSION}

This research is expected to contribute positively to the efforts of $\mathrm{MoE}$ in fulfilling one of the major educational policy, which is to inculcate and nurture national consciousness through fostering common ideas, values, aspirations and loyalties in moulding national unity and national identity among Malaysian students as the text selection really play a major role in influencing the students' development of intercultural competence. Due to the intercultural nature of Malaysia, which consists of citizens of different cultures, racial and religion background, it is pertinent to nurture the intercultural values among them beginning at primary school level. Implementing the recommendations of this research will be a part of the initiatives to properly instill the values and at the same time is a step forward in achieving the goal of MoE in achieving unity among a multi-ethnic society. As such the implementation can be navigated by the education policy makers, curriculum designers and literature 
text selection committee in recognizing cultural diversity elements in MELT and choosing suitable MELT for promoting intercultural competence among Malaysian national school students.

\section{REFERENCES}

Adam, H., \& Harper, L. (2016). Assessing and selecting culturally diverse literature for the classroom. Practical Literacy: The Early \& Primary Years, 21(2), 10-14.

Anderson, R. (1994). Role of the reader's schema in comprehension, learning, and memory. In. R. Ruddell, M. Ruddell, \& H. Singer, (Eds.), Theoretical models and processes of reading ( $4^{\text {th }}$ ed., pp. 469-482). Newark, Del: International Reading Association.

Ashwill, M. A., \& HoàngOanh, D. T. (2009). Developing Globally Competent Citizens: The Contrasting Cases of the United States and Vietnam. In. D. K. Deardorff (Ed.), The SAGE Handbook of Intercultural Competence. London: Thousand Oaks.

Badger, R. and MacDonald, M. (2007). Culture, Language, Pedagogy: The Place of Culture in Language Teacher Education. Pedagogy, Culture \& Society, 15(2), 215-227.

Bennett, J.M. (2008) Contemporary Leadership and Intercultural Competence: Understanding and Utilizing Cultural Diversity to Build Successful Organizations. Thousand Oaks, CA: Sage.

Bishop, R. (1997). Selecting literature for a multicultural curriculum.In V. J. Harris (Ed.), Using multiethnic literature in the K-8 classroom (pp. 1-20). Norwood, MA: Christopher-Gordon.

Bortoli, M.D. \& Maroto, J. (2001). Translating colours in web site localisation. Proceedings of the European Languages and the Implementation of Communication and Information Technologies (Elicit) Conference. University of Paisley. ISBN: 0-9541774-0-1.

Bredella, L. (2003). Afterword: What does it mean to be intercultural? In G. Alred, M. Byram and M. Fleming (Eds.), Intercultural experience and education (pp. 225239). Clevedon: Multilingual Matters.

Curriculum Development Council. (2012). Moral and National Education Curriculum Guide (Primary 1 to Secondary 6). Retrieved from http://www.edb.gov. $\mathrm{hk} /$ attachment/en/curriculum-development/moral-national- edu/MNE\%20Guide\%20(ENG)\%20Final_remark_09102012.pdf

Farahmandian, H. (2012). Shih Li Kow's Ripples: A Departure from Earlier Malaysian Literature in English Texts. International Journal of English Languge and Literature Studies, 1 (2), 38-46.

Ganakumaran, S. (2003). Literature programmes in Malaysian schools: A historical overview. In S. Ganakumaran \& Malachi Edwin, V. (eds). Teaching of literature in ESL/EFL contexts (pp. 27-48). Petaling Jaya: Sasbadi Sdn. Bhd

Garza, T. (2008). Culture in Foreign Language Teaching: The Fifth Skill," teacher training module for on-line methods course, funded through the Texas Higher Edu- cation Coordinating Board, 2008-2010.

Ghazali, S.N., Setia, Roszainora, S., Muthusamy, C., \& Jusoff, K. (2009). ESL Students's Attitude towards Texts and Teaching Methods Used in Literature Classes. English Language Teaching, Vol 2 (4), 51- 56.

Ghosn, I. (2002). Four good reasons to use literature in primary school ELT. English Language Teachers Journal (ELT), 56(2), 172-179.

González-Rodríguez, L. M., \& Borham-Puyal, M. (2012). Promoting intercultural competence through literature in CLIL contexts. ATLANTIS Journal of the Spanish Association of Anglo-American Studies, 34(2), 105-24.

Gunning, T. G. (1996). Creating Reading Instruction for All Children ( $2^{\text {nd }}$ ed.). New York: Allyn and Bacon Publishing Co. Inc.

Harper, L. J., \& Trostle-Brand, S. (2010). More alike than different: Promoting respect through multicultural books \& literacy strategies. Childhood Education: Journal of the Association for Childhood Education International, 86(4), 224-233.

Jia, W.L. (2017). Testing the Test: Exploring Conceptualisations of English Literature in Post-16 Literature Assessment. 3L: The Southeast Asian Journal of English Language Studies. Vol 23 (1), 35-48.

Kaur, P. (2002). Exploring Attitudes towards Reading English Materials of University ESL Students. UKM, Bangi: Language Policy and Practice for Nation Building.

Kaur, P., \& Mahmour, N. (2014). Examining the Role of the English Literature Component in the Malaysian English Curriculum. Procedia - Social and Behavioral Sciences, 134, 119-124. doi:10.1016/j.sbspro.2014.04.229.

Khader, F. (2012). The Malaysian Experience in Developing National Identity, Multicultural Tolerance and Understanding through Teaching Curricula: Lessons Learned and Possible Applications in the Jordanian Context. International Journal of Humanities and Social Science, 2(1).

Kitao, K. S. (1990). Textual schemata and English language learning. Cross Currents, 40(3), 147-155.

Ling, S.@ M.L. \& Eng, C. S. (2016). Types of English Literature Teaching Approaches Preferred by Teachers in Secondary Schools in Miri, Sarawak. International Journal of Language Education and Applied Linguistics (IJEAL), 4, 1-14. Universiti Malaysia Pahang.

Luke, A. (2003). Literacy education for a new ethics of global community. Language Arts, 81(1), 20-23.

Macdonald, M., Badger, R., and Dasli, M. (2006). Authenticity, Culture and Language Learning. Language and Intercultural Communication, 6(3\&4), 250-261.

Magos, K. (2015). What the polar bear wanted in Africa: Promoting empathy through reading and writing intercultural stories for young children. Paper presented at the Proceedings of the International Conference of International Association of Intercultural Education and University of Ioannina: Cultural Diversity, Equity and Inclusion. Ioannina: University of Ioannina.

Manjet, K., Marsani, F.N.A., Jaganathan, P., Karupiah, P., \& Abdullah, A.S.N. (2017). Exploring Malaysian Based Intercultural Knowledge and Behaviour among Second- 
ary School Students through English Language Intercultural Reading Programme (ELIRP). Pertanika Journal of Social Sciences and Humanities, 25(3), 1383-1400.

Marsani, F.N.A., Manjet, K., Jaganathan, P., Karupiah, P., Abdullah, A. S. N. (2016). A Study on the Level of Intercultural Knowledge among Malaysian Secondary School Students. International Journal of Applied Linguistics and English Literature, 5(6), 18-25.

McKay, S. L. (2001). Literature as content for ESL/EFL. In M. Celce-Murcia. (ed). Teaching English as a second or foreign language, $3^{\text {rd }}$ ed., (pp. 319-332). Boston: Heinle \& Heinle.

Malaysia Demographics Profile 2014. (n.d.). Retrieved December 15, 2015, from http://www.indexmundi.com/ malaysia/demographics_profile.html

Miles, M. B. \& Huberman, A. M. (1994). Qualitative Data Analysis: A Sourcebook of New Methods. California; SAGE publications Inc.

Mingfing Ho (2008). Literature component for secondary schools. Kementerian Pendidikan Malaysia.

Ministry of Education (2010). Malaysia: Education for All. Ministry of Education, Kuala Lumpur.

Ministry of Education. (2011). Teacher's resource book English literature component for Form 2. Putrajaya: Curriculum Development Division, Ministry of Education Malaysia.

Ministry of Education Malaysia. (2012). Preliminary Report Malaysia Education Blueprint 2013-2025. Retrieved May 20, 2016, from http:/www.moe.gov.my/userfiles/ file/PPP/Preliminary-Blueprint-Eng.pdf.

Ministry of Education Malaysia. (2002). Curriculum Specifications for English, Form 4. Kuala Lumpur: Dewan Bahasa dan Pustaka.

Najeemah, Y. (2006). Patterns of Social Interaction between Different Ethnic Groups in Malaysia. Jurnal Pendidik dan Pendidikan, 21, 149-164.

Ong, P. L., H., Ong, T.P.T., \& Ong, P. H. (2010). 3R, 1R or $3 R+1 R$ ? The teachers' dilemma. Procedia - Social and Behavioral Sciences 7: 191-200. http://dx.doi. org/10.1016/j.sbspro.2010.10.027.

Othna, S. \& Melor, Md. Y. (2016). English Literary Texts Used in Form Four and Five English Literature Component "Revisit". $1^{\text {st }}$ International Conference on Education, Universitas Negeri Malang. Retrieved on 20 October 2017 from pasca.um.ac.id/conferences/index.php/ ice/article/view/91/88

Pardede, P. (2010). A review \& on reading theories and its implication to the teaching of reading. Retrieved from https://parlindunganpardede.com/articles/language-teaching/a-

Pillai, S., Shoba Menon, P., \& Vengadasamy, R. (2016). The Marginalisation of Malaysian Texts in the English Language Curriculum and Its Impact on Social Cohesion in Malaysian Classrooms. Kajian Malaysia, 34(2), 25-58.

Quayum, M. A. (2003). Malaysian literature in English: Challenges and prospects in the new millennium. Silverfish New Writing 3, 179-194.

Rösch, O. (1993). MitStereotypenleben?Wie Deutsche und Russensichheutesehen. In: O. Rösch (Hrsg.), InterkulturelleKommunikation in den GeschäftsbeziehungenzwischenRussen und Deutschen, Berlin: News \& Media, 51-64. (WildauerSchriftenreiheInterkulturelleKommunikation; 1)

Shih Li Kow (2008), Ripples and Other Stories. Silverfish Books Sdn. Bhd.

Siew, C.C., Daljeet, S. S., Yow, L.L., Mun, Y. L., Malenee, A. \& Anuar, N. (2015). Influence of Culture on Students' Awareness of How and Why They Learn. Malaysian Journal of Learning and Instruction, 12, 49-67.

Sivapalan, S., \& Subramaniam, G. (2008). The incorporation of literature in the English Language Programme for Engineering Students: learner interest and perception. $3 L$ : The Southeast Asian Journal of English Language Studies. 14, 45-73.

Skopinskoja, L. (2003). The role of culture in foreign language teaching material: an evaluation from an intercultural perspective. In I. Lazar (ed.), Incorporating intercultural communicative competence in language teacher education (pp.39-59). Kapfenberg: Council of Europe Publishing.

Venthamani, M. E. (2004). Developments in teaching of literature in English. Serdang: Universiti Putra Malaysia Press.

Wan Kamariah Baba. (2009). An Investigation Into teachers' and students' attitudes towards literature and its use in ESL classrooms: a case study at Matriculation Centre in Malaysia. Unpublished Doctoral Thesis.

William T., Donnelly \& Arora K. (2016). Research Methods the Essential Knowledge Based. Wadsworth Publishing: US. 